\title{
Aan de hand van de patiënt
}

\section{Een pleidooi voor de patiënt als leermeester}

\author{
Sterven is geen alledaags gespreksonderwerp. Hospicearts
}

Christiaan Rhodius wil daar verandering in brengen door zijn

lessen over palliatieve zorg aan geneeskundestudenten.

Ons praten over mijn dood heeft me goed gedaan, vertelde een patiënt me, toen ik, naast mijn werk in Bardo, ook onderdeel was van het Team Ondersteunende en Palliatieve Zorg van het Spaarne Gasthuis. Deze opmerking raakte me. Hij laat iets zien van hoe er wordt omgegaan met de dood. Niet zelden is de dood als een roze olifant die pontificaal in de kamer staat, maar die toch genegeerd en doodgezwegen wordt.

\section{Roze olifant}

Tijdens mijn geneeskundestudie was ik vrijwilliger bij hospice Kuria in Amsterdam. Daar groeide bij mij het besef dat patiënten en hun naasten leermeesters zijn. Leermeesters die me onder andere lieten ervaren dat het gesprek over 'de roze olifant' mogelijk was. Sterker nog, samen de dood in de ogen kijken is een cruciaal onderdeel van goede zorg. Moeilijke thema's bespreekbaar maken, is een uiting van betrokken zijn bij de ander.

In de medische opleidingen is er maar heel beperkt aandacht voor palliatieve zorg. En al helemaal weinig over het praten over 'de roze olifant'. En dat is gek als je beseft dat ieder mens sterfelijk is en dus te maken krijgt met de laatste levensfase.

\section{Gesprek met patiënt}

In de minor Comprehensive Care and Anatomy, onderdeel van de bacheloropleiding aan de faculteit der Geneeskunde van de VU, voeren studenten een gesprek met een patiënt in een hospice. De afgelopen jaren kwamen studenten ook naar hospice Bardo, maar door COVID-19 kon dat in 2020 niet. Om de patiënt toch een stem in het onderwijs te geven, nam ik een gesprek met een patiënt op film op. Deze film liet ik de studenten zien.

In de film wisselen de patiënt en ik van gedachten over 'de roze olifant', en het gevoel van de patiënt dat er niet over zijn dood gesproken kon worden. En hoe hij dat als een beletsel heeft gezien van goede zorg. Vanuit zijn eigen perspectief reikt de patiënt voor de jonge dokters o.a. aan hoe het gesprek met de patiënt gestart kan worden. De introductie van de film is te zien op YouTube: youtu.be/t-DDQBtsMUc. Hierin schets ik kort de dood als onlosmakelijk onderdeel van het leven, de inzet van palliatieve zorg en het belang te achterhalen wat leven voor de patiënt betekent (lees: wat er (nog) mogelijk gemaakt moet worden). Ook de verdieping in het patiëntencontact, die denken over eigen sterfelijkheid geeft, stip ik aan. Het gesprek zelf is - buiten scholingsactiviteiten om vanwege privacy niet te bekijken. Studenten wisselden na het bekijken van het gesprek opgedane indrukken en lessen uit. Twee uitspraken van hen:

"Door het bekijken van dit gesprek heb ik me gerealiseerd dat het erg waardevol kan zijn voor de patiënt om de dood niet uit de weg te gaan, maar deze juist al op een vroeg moment in het ziektetraject te benoemen. [...] Het lijkt mij mooi om later als arts een luisterend oor te kunnen bieden aan mijn patiënten en een open omgeving te creëren waarin praten over de dood geen probleem is."

"Iets wat me bijblijft is dat praten over het proces van de dood niet per definitie negatief en slecht hoeft te zijn. Het kan zelfs positieve kanten met zich meebrengen."

Als de toegevoegde waarde van onderwijs over palliatieve zorg en de rol van de patiënt daarin nog niet duidelijk was, dan hopelijk nu wel.

In nagedachtenis aan al mijn leermeesters. Dat jullie lessen anderen ten goede mogen komen.
Door C. Rhodius 